\title{
エポキシ樹脂塗り床の付着性に及ぼすセメントモルタルの 表面粗さの影響
}

\section{EFFECTS OF SURFACE ROUGHNESS ON ADHESION BETWEEN EPOXY RESIN FLOOR COATINGS AND CEMENT MORTAR SUBSTRATE}

\author{
内田昌宏*1, 田中享二*2 \\ Masahiro UCHIDA and Kyoji TANAKA
}

\begin{abstract}
Effects of surface roughness on adhesion between epoxy resin floor coatings and cement mortar substrate were discussed. First surface roughness and waviness of various cement mortar substrate which were abraded through various abrasive papers were measured. Second, peel energy was measured. In stead of cement mortar substrate, the gypsum replicas were used in the measurement for avoiding an influence of wide variety of surface free energy of cement mortar substrate. The peel energy between the gypsum replicas and epoxy resin floor coatings was discussed. It was found out that peel energy closely related to the surface roughness of substrate, and an increase of surface roughness was effective in improving adhesion between the substrate and the coatings.
\end{abstract}

\section{Keywords : surface roughness, epoxy resin, floor coatings, cement mortar, peel energy \\ 表面粗さ，エボキシ樹脂，塗り床，セメントモルタル，剥離エネルギー}

1.はじめに

コンクリートを下地として㓌布されたエポキシ樹脂凃り床材には、 下地水分の影響によりふくれが発生することがある。ふくれは多く の場合、直径が数十ミリメートル以下のものが多数点在して現れ ${ }^{12}$ 、 この現象を付着の観点から見ると、ふくれ部分は下地コンクリート とエポキシ樹脂塗り床材間での局部的な付着結合の破壊と理解する ことができる。

塗り床材の下地への付着は、付着結合の形成による。付着結合の 形成とは、塗り床材が下地にぬれ㹡がる、いわゆる「ぬれ形成す る」ことであり、このぬれの形成は塗り床材と下地との関係を界面 化学理論によって説明することが出来る ${ }^{2)}$ 。

エポキシ樹脂塗り床材の付着性に及ぼす下地の界面化学的要因に

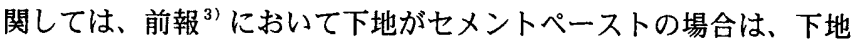
の表面自由エネルギーのうち、極性力成分（永久双極子を有する分 子によるKeesom力、誘起双極子によるDebye力、及び水素結合力な どのエネルギー成分を示す）が大きくなると剥離エネルギーも大き くなり、㓌り床材は剥がれにくくなることを明らかにした。また、 下地を乾燥、研磨、緻密化することは極性力成分を大きくする方向 に作用し、これにより付着仕事は増大し、その結果として付着力は 向上することを示した。
しかし、前報 ${ }^{3)}$ までの段階では機械的吸着力（いわゆるアンカー 効果）は考虑されていないが、実際の下地コンクリートと塗り床材 との付着強さは、この機械的吸着力の影響も強く受けると考えられ $る^{4)}$ 。

付着性に及ぼす下地表面粗さの影響に関する既往の研究の中で、 金属下地については、场内ら ${ }^{5)}$ が表面粗さが大きすぎても、小さす ぎても付着強さは極大とはならず、最適な表面粗さが存在すること を示している。同様に佐藤 ${ }^{4)}$ は接着面の表面粗さが、接着強さを向 上させる効果と減少させる効果の両方を有していて、どの程度の表 面粗さが最も有効であるかは、塗料と被塗物との組み合わせにより 異なるので、それぞれの場合に表面粗さを変えて接着性との関係を 検討することが必要であると指摘している。またJennings ${ }^{6)}$ は表面 を具体的に調整する方法の中で表面粗さと接着力との関係を論じ、 サンドブラスト処理が最も効果があり、研磨紙処理では最適粒度が あるとしている。一方、下地がセメント硬化体である場合は、国原 ら”が被着面の粗さが付着強さに与える影響を検討しているが、明 確な傾向を見い出せないでいる。これはセメント硬化体が被着体と して壊れ易いため、適切な付着強さの評価が難しかったことが原因 と考えられる。

前報 ${ }^{3)}$ では、付着強さに及ぼす界面化学的要因を抽出して考察す

\footnotetext{
*1 (侏)エービーシー建材研究所, 東京工業大学大学院

*2 東京工業大学建築物理研究センター 教授・工博

ABC Research Laboratory for Building Materials Co., Ltd.

Graduate School, Tokyo Institute of Technology

Prof., Structural Engineering Research Center, Tokyo Institute of Technology, Dr. Eng.
} 
るため、可能な限り平滑な下地として表面粗さを均一に保つ工夫を 講じたが、本研究では、下地として十分な強度を有し、且つ界面化 学的要因を一定に保つことが出来る均一配合の石高レプリカを用い ることにより、適切な付着強さの評価を可能にした。そしてこの評 価方法に基づいて、下地表面の機械的吸着力を抽出することを可能 にし、下地表面の凹凸、特に表面粗さが付着強さに与える影響を検 討した。

\section{2. 下地表面の凹凸}

下地としてのコンクリート表面の凹凸は、いろいろな条件の影響 を受ける。そこでコンクリート表面の凹凸に影響を与える要因を明 らかにすることを目的として、表面の処理方法、処理の時期、及び 調合の異なる下地を作製し、その表面の凹凸の測定を行った。

\section{1 下地}

一般的に塗り床材が塗布される下地は普通コンクリートである。 しかし塗り床材が塗布される下地表面は、粗骨材が現れていないモ ルタル面であり、また試験体としての取り扱い易さを考慮して試験 用下地はセメントモルタルとした。下地モルタル板の作製フローチ ヤートを図1に示す。

\section{（1）下地モルタル板の調合及び作製方法}

下地モルタル板は、水セメント比 $45 \%$ ，60\%、75\%として、 フロー值が $195 \mathrm{~mm}$ 程度となるような表 1 に示す調合とした。モ ルタル板は $70 \times 70 \times 20 \mathrm{~mm}$ の板状に打設し、打設 1 日後より 所定期間封絾養生したのち、打設表面を以下の（3）に示す研磨紙 にて十分に研磨した。研磨後のモルタル板は、アセトンに 2 時間浸 せきし、さらに 1000 Cにて 7 日間十分に乾燥させて使用した。な おセメントは普通ポルトランドセメントを、細骨材は豊浦産旧標準 砂を使用し、打設及び荃生温度は $20^{\circ} \mathrm{C}$ とした。

（2）表面押さえ及び盖生条件

セメントモルタル打設時の表面の押さえは、木鏝押さえと金鏝押 さえの 2 種類とした。通常、塗り床が施工される下地コンクリート は金鏝押さえであるが、機械的吸着力に関する付着性を考慮した場 合、木鏝押さえの表面粗さがより適することも考えられるため、試 験体として木鏝押さえも用意した。ただし、木鏝押さえモルタル板 については所定期間封絾養生後の研磨は行わず、打設面をそのまま 試験面とし、表面の押さえは、現場に做つて木鏝押さえは打設 2 時 間後に 1 回とした。金鏝押さえの場合は 1 試験体に付き打設 2 時間 後、 3 時間後、 4 時間後、及び 5 時間後の計 4 回行った。羡生期間 は7 日、28日、60日、90日とした。

\section{（3）下地表面研磨}

塗り床材が施工される下地としては一般に金鏝押さえコンクリー トであり：さらに塗り床材施工前に表面が研磨される。この状態を 再現するために、所定期間養生後の金鏝押さえのモルタル板表面を、 J I S R 6252 規定の研磨紙により研磨した。研磨紙は、施工現 場において予想される滑らかな下地から、表面凹凸の大きい下地を 網羅するように、番手\#20、\#50、\#80、\#180、\#500、\#2000の炭化珠素質 研磨紙を使用し、研磨方向は現場における塗り床下地コンクリート の研磨方法にならって円形状に研磨した。結局、試験体としては各

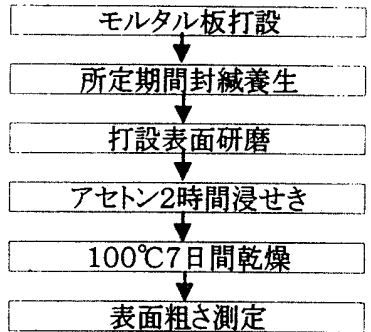

图1 モルタル板の作製フローチャート

\begin{tabular}{|c|c|c|c|c|}
\hline 水セメント比 (\%) & 水 $(\mathrm{g})$ & セxント(g) & 細骨材 (g) & フロ一值( $(\mathrm{mm})$ \\
\hline 45 & 225 & 500 & 675 & 196 \\
\hline 60 & 300 & 500 & 1050 & 195 \\
\hline 75 & 375 & 500 & 1325 & 194 \\
\hline
\end{tabular}

表2 下地弃面を表す曲線

\begin{tabular}{|c|c|c|}
\hline 曲線の名称 & 概 & 定義規定 \\
\hline 断面曲線 & $\begin{array}{l}\text { 対象面に直角な平面で対象面を切断したとき } \\
\text { にその切り口に現れる輪郭 }\end{array}$ & 0601 \\
\hline 粗さ & 断面曲線から表面うねり成分を除去した曲線 & \\
\hline $\begin{array}{l}\text { 万波うねり } \\
\text { 曲線 }\end{array}$ & $\begin{array}{l}\text { 断面曲線から波長が然い表面粗さの成分を } \\
\text { 低域フィルタによって除去して得られる曲線 }\end{array}$ & JIS B 0610 \\
\hline $\begin{array}{l}\text { ろ波中心線 } \\
\text { うねり曲線 }\end{array}$ & $\begin{array}{l}\text { ろ波うねり曲線から波長が長い成分を除去し } \\
\text { て得られる曲線 }\end{array}$ & 0610 \\
\hline
\end{tabular}

表3 測定パラメータ

\begin{tabular}{|c|c|c|}
\hline $\begin{array}{c}\text { パラメータの名称 } \\
\text { 略号(単位) }\end{array}$ & 概 要 & 定義規定 \\
\hline $\begin{array}{c}\text { 算術平均粗さ } \\
\operatorname{Ra}(\mu \mathrm{m})\end{array}$ & $\begin{array}{l}\text { 眐面曲線からうねり成分を除いた粗さ曲線 } \\
\text { において、その中心線と粗さ曲線との偏差 } \\
\text { の絶対值を算術平均した値 }\end{array}$ & JIS B 0601 \\
\hline $\begin{array}{c}\text { ろ波中心線うねり } \\
\text { Wca }(\mu \mathrm{m})\end{array}$ & $\begin{array}{l}\text { ろ波中心線うねりの中心線とろ波中心線うね } \\
\text { り曲線との偏差の絶対值を算術平均した值 }\end{array}$ & \\
\hline
\end{tabular}

水セメント比毎に、金鏝押さえモルタルは研磨無しを含めて 7 種類、 木鏝押さえモルタルは研磨無しのみの 1 種類を用意した。

\section{2 ． 2 表面の凹凸の測定}

表面の凹凸の成分は、きわめて稳やかな変化を表す幾何学的形状 からの狂いの成分である「形状偏差」、やや長波長で稳やかに変化 する「表面うねり」、さらに波長が短く不規則に変化する「表面粗 さ」の成分からなっている ${ }^{8)}$ 。本研究では機械的吸着力に係わる付 着強さを検討の対象としているため、表面の凹凸の成分のうちミク 口的な凹凸を示す表面うねりと表面粗さの両者を測定の対象とした。 一般的に表面うねりと表面粗さは、表 2 に示すような断面曲線、 粗さ曲線、万波うねり曲線及びろ波中心線うねり曲線により表され る。本研究では表 3 に示すように、表面うねり成分を除去した表面 粗さを評価することを目的として、粗さ曲線の中心線からの偏差を 示す算術平均粗さ $\mathrm{R}$ a を、表面うねりを評価することを目的として、 ろ波中心線うねり曲線の中心線からの偏差を示すろ波中心線うねり W c a を調べた。

この下地表面粗さ及び表面うねりを示す 2 つのパラメー夕、 $\mathrm{R} a 、 W \mathrm{c}$ a を、走査型レーザ顕微鏡（レーザテック（株）製 $1 \mathrm{~L}$ M $21 \mathrm{~W}$ ）により測定した。測定長さは $1.0 \mathrm{~mm} \pm 0.1 \mathrm{~mm}$ と し、1 試験体につき 3 力所測定し、その平均值を測定值とした。 


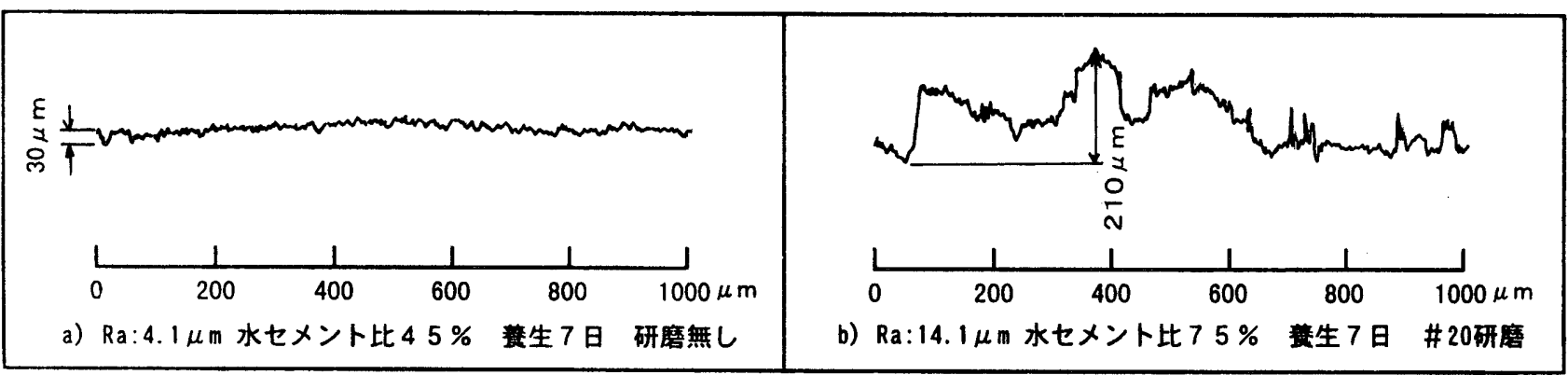

図 2 下地の断面曲線
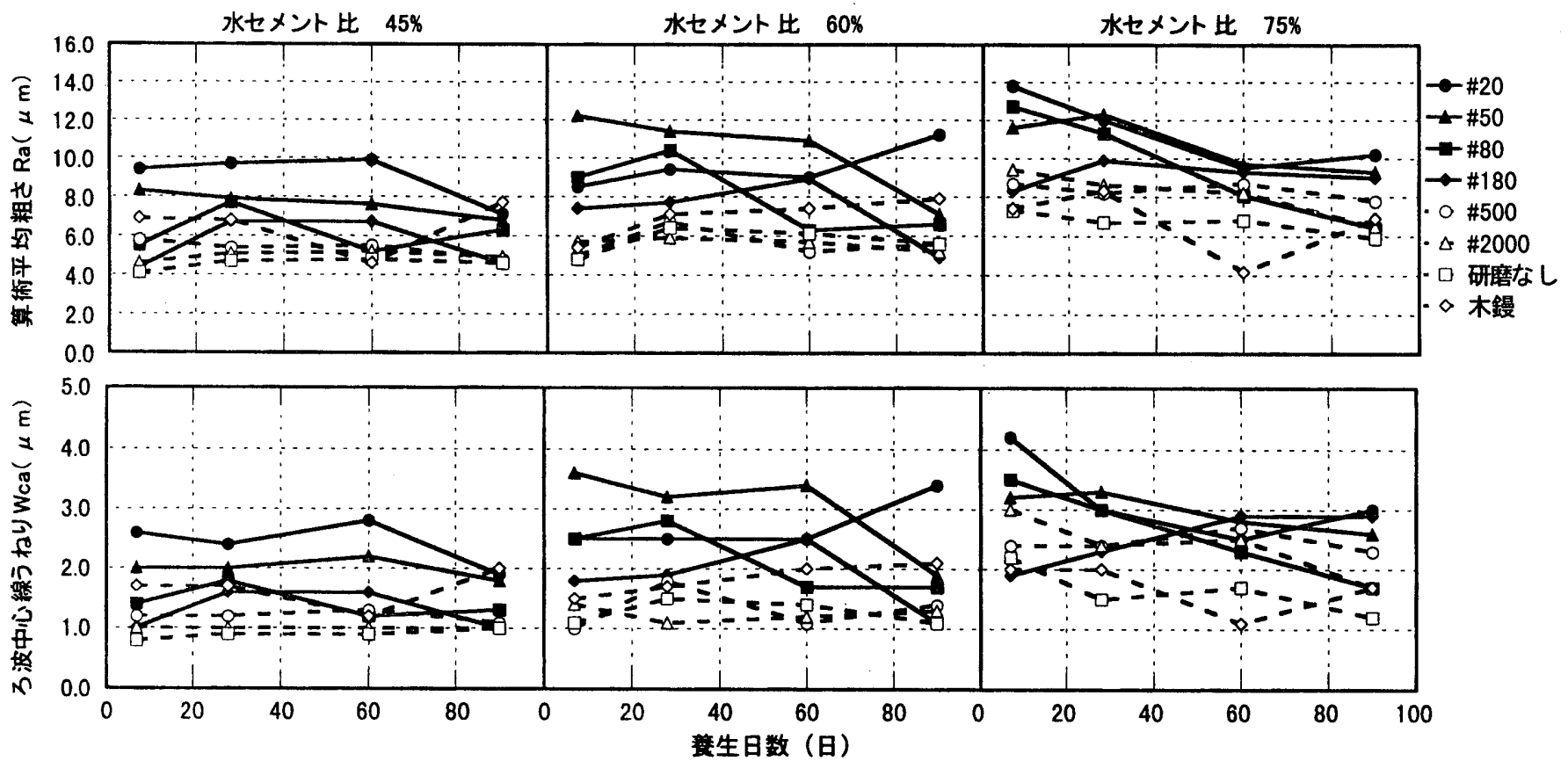

図 3 下地の表面粗さ及び表面うねり

\section{3 測定結果と考察}

(1) 下地の表面凹凸

下地モルタル板のうち、表面凹凸の小さいものと大きなものの代 表的な断面曲線を図 2 に示す。算術平均粗さ $\mathrm{R}$ a が $4 \mu \mathrm{m}$ 程度の下 地は、凹凸が $30 \mu \mathrm{m}$ 程度であり、算術平均粗さ $\mathrm{R}$ a が $14 \mu \mathrm{m}$ 程 度の下地は、凹凸が $210 \mu \mathrm{m}$ 程度である。表面のレイタンス除去 を目的として研磨が行われる一般的な現場の塗り床下地は、本研究 で使用した下地モルタル板の凹凸の範囲にほほ含まれると判断され る。

（2）養生期間の影響

下地の算術平均粗さ $\mathrm{R}$ a 及びろ波中心線うねりW c a の測定結果 を図 3 に示す。これによると養生期間による傾向は明確ではなかっ た。

（3）表面粗さと表面うねりの関係

一般に表面の凹凸の周波数成分は、フーリエ解析すると高周波数 成分から低周波数成分まで連続的に分布している ${ }^{8)}$ 。従って表面う ねりと表面粗さとは独立したものではなく相互に影響を及ぼしあっ ていると考えられる。そこで、表面粗さのパラメータである算術平 均粗さ $\mathrm{R}$ a と、表面うねりのパラメータであるろ波中心線うねり

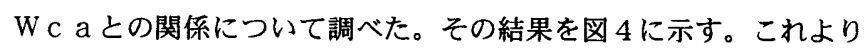
算術平均粗さ $\mathrm{R}$ a とろ波中心線うねり W c a とは相関係数が 0.98 と

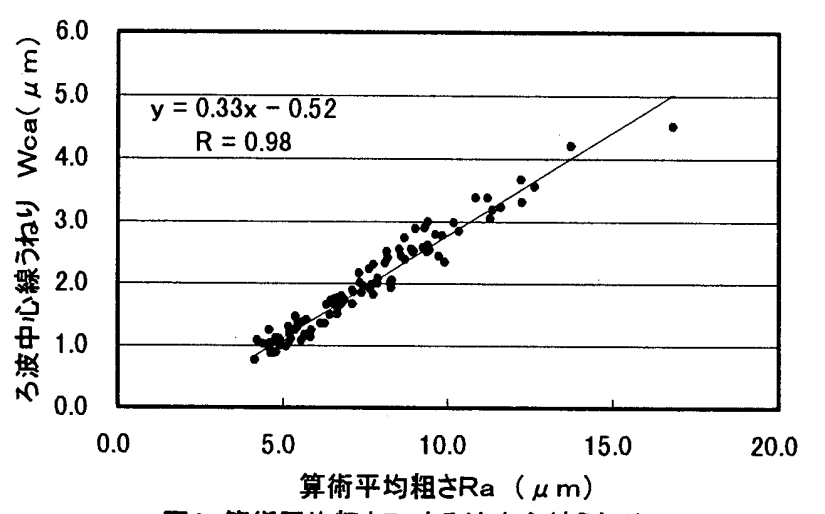

図4 算術平均粗さRaとろ波中心線うねりWca

高い相関関係を有し、表面粗さが大きくなると表面うねりも大きく なることが明らかである。従って、本研究では表面粗さを調べるこ とにより、表面うねりも含んだ下地表面の凹凸全体について評価が 出来ると考えられる。従って以後、表面粗さに関してのみ検討する こととした。

\section{（4）表面粗さと水セメント比及び研磨紙の番手}

研磨下地モルタル板について、水セメント比毎に整理した研磨紙 番手と算術平均粗さ $\mathrm{R}$ a との関係を図 5 に示す。水セメント比が大 きくなるほど、算術平均粗さ $\mathrm{R}$ a は大きい傾向にあり、表面粗さは 


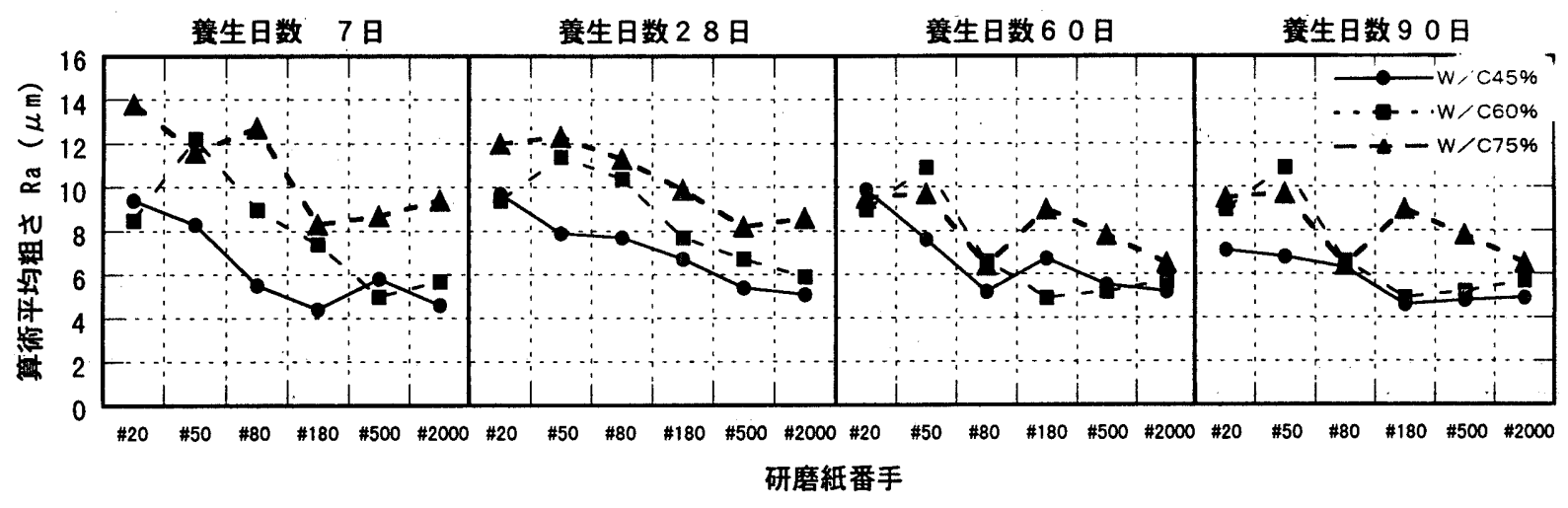

图 5 研磨紙番手と算術平均粗さ

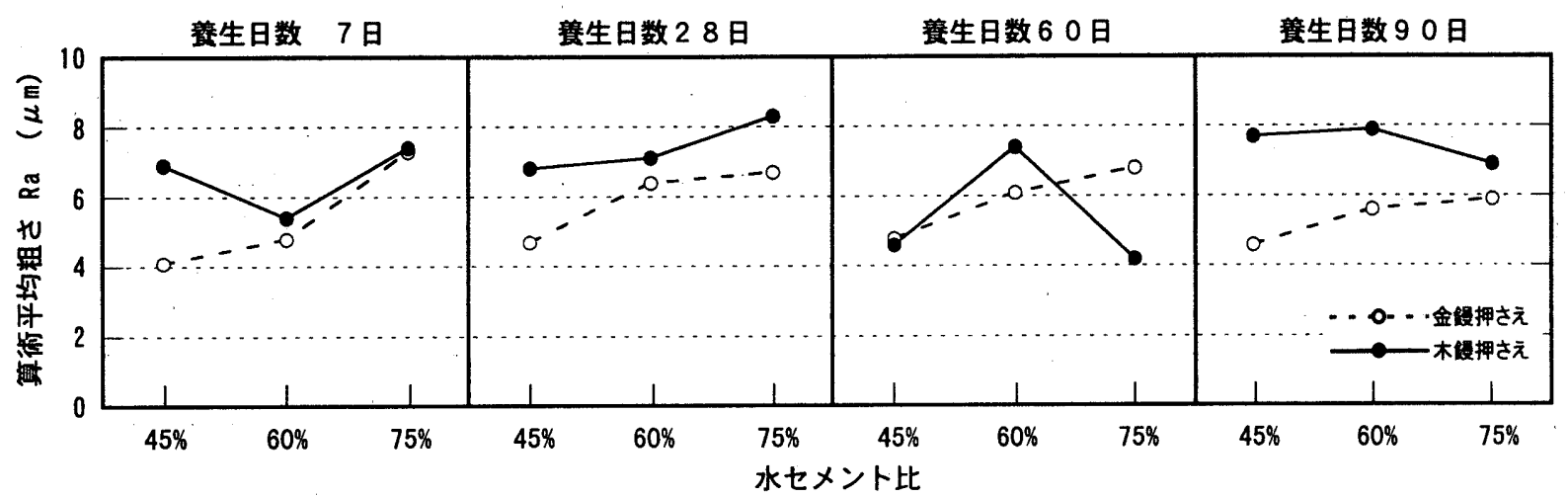

图 6 下地表面押さえの違い

大となる。これは、水セメント比が大きいほど下地の組織が粗であ り、研磨され易いためと考えられる。また研磨紙の番手が小さいほ ど表面粗さは大きく、算術平均粗さ $\mathrm{R}$ a は最大で $14 \mu \mathrm{m}$ 程度であ った。

\section{（5）表面押さえの違い}

非研磨下地モルタル板について、表面押さえ別にまとめた算術平 均粗さ R a を図 6 に示す。養生日数 60 日水セメント比 $75 \%$ を除 いて、木鏝押さえ表面は金鏝押さえ表面と同等又はより大きな表面 粗さを示した。しかし木鏝押さえ下地モルタル板の算術平均粗さ $\mathrm{R}$ a は最大でも $8 \mu$ 程度であり、より大きな表面粗さの下地を得る には、水セメント比の大きな下地を小さい番手の研磨紙で研磨する ことが望ましいと考えられる。

\section{3. 付着強さ}

3. 1 付着強さ試験用下地

前報 ${ }^{3)}$ において: セメントペーストは水セメント比、乾燥、研磨、 及び組織の緻密の程度の違いにより、界面化学的な表面自由エネル ギーが変化し、付着強さも影響を受けることを示した。本研究では 機械的吸着力が付着強さに与える影響のみを検討することを目的と しているため: 表面自由エネルギーが試験体間で変化しない均一配 合の石育レプリカを付着強さ試験用下地とした。レプリカ下地の作 製フローチャートを図 7 に示す。

\section{（1）レプリカ下地作製前の原下地}

レプリカ下地作製前の原下地は、2．表面粗さ及び表面うねりの 測定に使用したモルタル板のうち、封縅養生 28 日後のモルタル板 を原下地とした。

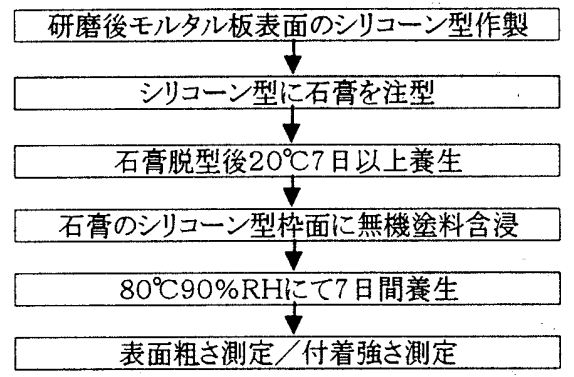

図7レプカ下地の作製フローチャート

表4 石亳の性状

\begin{tabular}{cccc} 
混水率 $(\%)$ & 硬化時間 (分) & 硬化膨張率 (\%) & 圧縮強さ \\
\hline 24 & 10 & 0.15 & 51
\end{tabular}

\section{表5 無機涂料の性状}

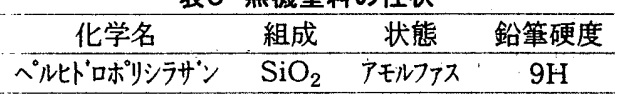

\section{（2）レプリカ下地の作製}

図 7 に示すように研磨後のモルタル板を常温硬化型シリコーンゴ ムで型取りし、表 4 に示す性状の高強度石高を流し込み硬化させる。 脱型後 $20{ }^{\circ} \mathrm{C} に て 7$ 日以上養生後、表面強度の向上を目的として石 高のシリコーン型面に表 5 の無機塗料を均一に含浸硬化させ、 80 ${ }^{\circ} \mathrm{C} 90 \mathrm{RH} \%$ で 7 日間養生しレプリカ下地とした。

（3）レプリカの表面粗さの確認

前記 2 . 2 と同椂の方法にてレプリカ下地の算術平均粗さ $\mathrm{R} a$ を 
測定した。測定位置は任意の 3 力所とし、その平均值を測定值とし た。モルタル板とレプリカ下地の相互の算術平均粗さ $\mathrm{R}$ a の関係を 図 8 に示す。また表 6 に二元配置法による分散分析結果を示す。同 種の試験体差、下地の種類差は共に有意であるが、下地の種類差の 寄与率が小さいこと、及びモルタル板とレプリカ下地の相関係数が 0.9と高いことより、レプリカ下地にてモルタル板を置換出来る ものと判断した。

\section{2 工ポキシ樹脂塗り床材}

エポキシ樹脂塗り床材は、一般的な塗り床材の配合に準じて、基 材にビスフェノールAタイプの液状エポキシ樹脂を主として配合し、 これを反応性希採剤で希釈したビヒクルを使用した。また硬化剂に は変性脂肪族ポリアミンを使用した。その配合及び性状を表 7 に示 す。

\section{3. 付着強さ試験}

3. 3. 1 測定方法

付着強さ試験は、従来カーボン繊維補強エポキシ樹脂に関しては、 V.M.Karbhari $5^{9)}$ の大型の剥離試験、逸見 $5^{10)}$ の皮剥式剥離試験、 守谷ら"1)のペルジャ一式接着試験などの多くの試験法があるが、 これらの試験方法では表面粗さが付着強さに与える影響を考察する には、スケールが大きすぎ不適切である。

エポキシ樹脂塗り床材のふくれは発生初期は直径数 $\mathrm{mm}$ と微小で あり、またふくれの成長は剥離により進行すること、またふくれが 塗り床材と下地との界面で生じていることを考慮し、本研究におけ る付着強さの測定方法は、前報 ${ }^{3)}$ と同様に、作業可能な最小幅で破 壊状態が界面破壊となる微小剥離試験が適当と考えた。すなわち、 以下に示すようにKendall の提案している試験方法をエポキシ樹脂 塗り床材とセメントペーストとの剥離試験に応用できるように改良 し試験方法とした。

Kendal1 ${ }^{12)}$ によると、図 9 のように下地に付着したテープを角度 $\theta$ で引っ張った際の剥離エネルギー $\mathrm{f}$ は、（1）式で表される。

$$
f=F(1-\cos \theta) / b
$$

$\mathrm{F}$ はテープが剥離した際の引張応力であり、bはテープの幅であ る。

本研究では、図 10 に示すように幅 $2 \mathrm{~mm} \times$ 厚さ $1 \mathrm{~mm} \times$ 長さ 100 mmのエポキシ含浸ひも状体（ひもには試験時にほとんど伸びの生じ ないアラミドフィラメントを使用）を上記エポキシ樹脂塗り床材で 下地に貼り付け、 $20{ }^{\circ} \mathrm{C} 24$ 時間養生し、さらに $50{ }^{\circ} \mathrm{C} 24$ 時間養 生後、 $20{ }^{\circ} \mathrm{C} に て$ 徐冷した後、エポキシ含浸ひも状体を引っ張った。 引張速度は $1 \mathrm{~mm} /$ 分、引張角度は 5 度とし、単位幅当たりの引張 応力 F (dyn) を測定した。そして、（1）式により剥離強度エネ ルギー $\mathrm{f}\left(\mathrm{erg} / \mathrm{cm}^{2}\right)$ に換算し、付着強さを求めた。剥離エネルギー に換算したのは、前報 ${ }^{31}$ の界面化学的な考察と比較出来るようにす るためである。引張速度を $1 \mathrm{~mm} /$ 分としたのは、この速度以下で 試験を行った際の剥離エネルギーは、ほぼ一定であったためであり、 試験の効率を考慮してその中での最大の引張速度とした。引張角度 を 5 度としたのは、剥離エネルギーの差が明確に現れるのが 5 度程 度であり、また実際のふくれ端部の下地との角度は多くの場合 5 度 程度であったためである。

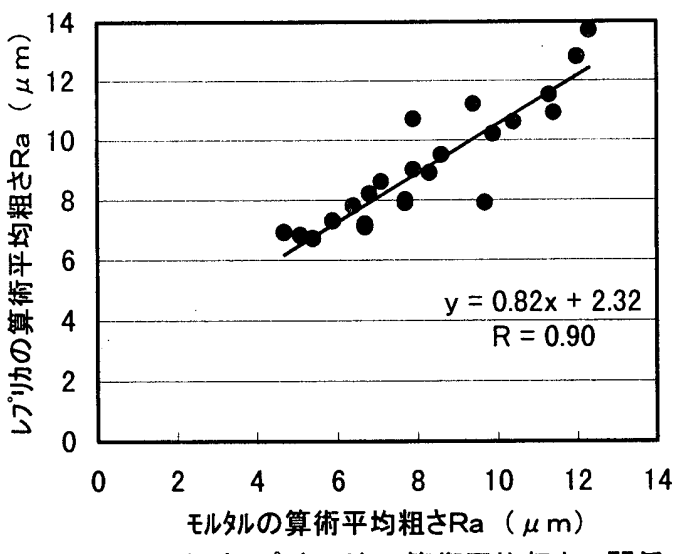

図8 モルタルとレプリカ下地の算術平均粗さの関係

表6 算術平均粗さRaの分散分析結果

\begin{tabular}{|c|c|c|c|c|}
\hline 項 & 目 & 分散比 & $\mathrm{F}(0.01)$ & 需与率 \\
\hline 同種の & 験体差 & $18.88^{* *}$ & 2.70 & 0.86 \\
\hline 下地 & 類差 & $19.68^{* *}$ & 4.28 & 0.04 \\
\hline
\end{tabular}

\begin{tabular}{|c|c|c|c|}
\hline \multirow{4}{*}{ 配合 } & \multirow{3}{*}{ 基材 } & 原料名 & 重量部 \\
\hline & & ピスフェノールAタイプ液状エポキシ樹脂 & 80 \\
\hline & & 2官能反応性エポキシ希釈剂 & 20 \\
\hline & 硬化剂 & 変性脂肪族ポリアミン & 40 \\
\hline \multirow{2}{*}{ 性状 } & 混合物 & 粘度 $\left(20^{\circ} \mathrm{C}\right) \mathrm{Pa} \cdot \mathrm{s}$ & 1.8 \\
\hline & 硬化物 & 引張り弾性係数 $\mathrm{MPa}$ & 1. $9 \times 10^{3}$ \\
\hline
\end{tabular}

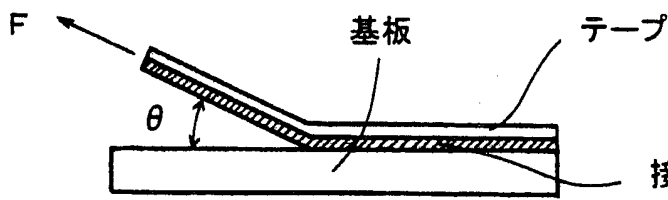

接管剂

図9 Kendallのテープ剥離試験

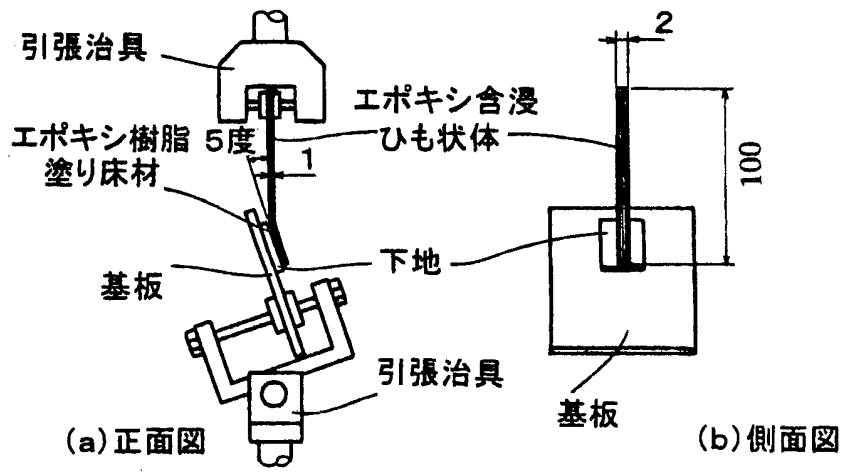

図10 付着強さ測定方法 


\section{3.2 測定結果及び考察}

図 11 に算術平均粗さ $\mathrm{R}$ a と剥離エネルギーとの関係を示す。算 術平均粗さ $\mathrm{R}$ a は は剥離エネルギーと正の相関があり、下地表面粗さ が増すと塗り床材は剥がれにくくなる。回帰式は（2）式のように なり、相関係数は 0.85 であった。

$$
\mathrm{Y}=(1.90 \mathrm{X}-4.49) \times 10^{4}
$$

表面粗さが最も大きい下地の剥離エネルギーは、表面粗さが最も 小さい下地の剥離エネルギーの約 3 倍となる。従って、下地を研磨 し表面粗さを大きくすることにより、下地の塗り床材に対する機械 的なアンカー効果も增大し、その結果として付着強さが大きくなっ たものと考えられる。

\section{4. 機械的吸着力の観点からみた下地表面粗さの考察}

モルタル下地についての塗り床材の剥離エネルギーは、本研究が 対象とした下地の範囲内では、下地表面粗さが増すに従い増大する。 一般的に下地が金属下地等の密封性が高く、不透過性の下地につい ては、佐藤 ${ }^{4)}$.や井本 ${ }^{13)}$ が述べているように、凹部への塗液の進入 は難しく、このため付着強さが極大となる最適表面粗さが存在する。 しかし本研究において対象としているもルタル下地は多孔体である こと、金属下地等と比較して格段に表面粗さが大きいこと、及び塗 液は無溶剤の 2 液硬化型エポキシ樹脂塗り床材であることから、表 面の凹部に硬化前の塗り㦿材がゆっくりとかつ十分に進入している と考えられ、これが下地表面粗さと剥離エネルギーに正の相関をも った理由と考えられる。従って塗り床材の付着性向上のためには、 下地表面粗さを大きくすることが効果的である。なお、㓌り床材の 塗布厚みより下地表面粗さが大きくなると、下地が露出したり塗り 㦿材表面が平滑に仕上がらないため、あくまで下地表面粗さは塗り 床材の仕上がりが不良とならない最大の大きさが上限となる。

\section{5. 結論}

コンクリートを構成するセメントモルタルに㓌布されるエポキシ 樹脂塗り床材の付着性について、機械的吸着力という観点から表面 粗さの影響について考察を行った。得られた本研究の結論は以下の 通りである。

（1）水セメント比を大きくすることは下地表面粗さを大きくする 方向に作用する。

（2）研磨が無い場合、木鏝押さえモルタルの表面粗さは、金鏝押 さえモルタルの表面粗さと同等、若しくはより大きな表面粗さとな る傾向にある。研磨する場合は、金鏝押さえ表面を番手の小さな研 磨紙等で十分に研磨する方が、表面粗さのより大きい表面が得られ る。

（3）表面粗さと塗り床材の剥離エネルギ一は正の相関があり、表 面粗さが増すに従い、剥離エネルギーは大きくなる。付着性向上の ためには、塗り床材の仕上げに影響を与えない範囲で、十分に下地 を研磨し表面粗さを大きくすることが効果的である。

ただし、以上の考察は機械的吸着力だけに着目したものであり、 付着性について総合的に考察するには前報 ${ }^{3)}$ で行った界面化学的考 察と合わせて判断する必要がある。これらについては今後の課題で ある。

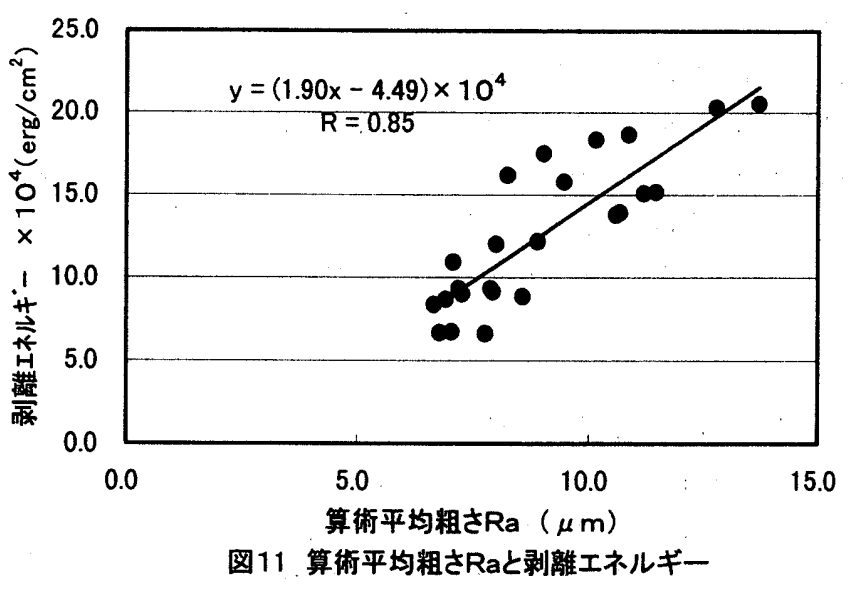

6. 謝辞

本研究を行うに当たり、（株）エービーシー建材研究所 横山光 男所長、大田皓士室長及び大西一昌室長には、大変お世話になりま した。また実験には、東京工業大学大学院生 安藤紀明氏の御協力 をいただきました。ここに深く謝意を表します。

\section{参考文献}

1）田中享二、内田昌宏、大森修、橋田浩、湯浅昇 : 清り床のふく れ発生機構の一考察; 日本建築学会構造系論文報告集, 第488号, pp $25-30,1996$

2）原崎勇次 : コ-テイ⿰グ の基礎科学, pp161,1980

3) 内田昌宏、田中享二 : エポキシ樹脂塗り床とセメントペースト の付着性に関する界面化学的考察 ; 日本建築学会構造系論文報告集, 第524号, pp21-27, 1999

4）佐藤弘三：塗膜の接着 理論と実際；接着, Vol. 42, No. 2, pp. 74 $-81,1998$

5) 珮内慶次、桐生春雄、佐藤弘三 : 塗膜の付着に及ぼす軟鎘板の 表面あらさの影響 ; 色材, Vo1.57, №. 5, pp. 255-258, 1984

6) C. W. Jennings:Surface Roughness and Bond Strength of Adhes ives; J. Adhes i on, Vol. 4, №. 25, 1972

7 ) 国原安彦、今泉勝吉、青山幹、林好正 : エポキシ樹脂系接着材 の性能評価（その 2 被着面の粗さの影響）;日本建築仕上げ学会大 会学術講演会研究発表論文集, pp. 119-122,1992

8 ）谷村吉久; 表面粗さの最近の動向 表面粗さの規格 ; トう怵 口シ 外, Vol. 43, No. 11, pp919-924, 1998

9) V.M.Karbhari and M.Engineer : On the use of a peel test for determination of concrete-composite bond durability; 40th International SAMPE Symposium, 1995

10）逸見義男、湯浅昇、佐藤弘和、松井勇、笠井芳夫：下地工刎一个 の含水状態及び細孔構造がエポキシ樹脂系塗り床材の接着性に及ぼ す影響；日本建築学会大会学術講演梗概集（A）,pp. 1393-1394, 1995

11）守屋正裕、川地武：コン夘一面塗膜の試験方法の提案；日本建築 学会大会学術講演梗概集 (A), ppl 401-1402, 1995

12) K. Kendall:The adhesion and surface energy of elastic solid ; J.Phys. D, Vol. 4, pp1186-1195, 1971

13）井本立也：塗膜の付着性 II 接着強さの推定と接着条件の影

響；実務表面技術; Vol. 32, No. 10, pp. 528-532, 1985 